\title{
Globalization and University Rankings: Consequences and Prospects
}

\author{
Hira Khan ${ }^{1}$, Khairul Anuar Mohammad Shah ${ }^{1}$, Jamshed Khalid ${ }^{1}$, Majed Ageel A Harnmal ${ }^{2,3}$ \& Anees Janee Ali $^{1}$ \\ ${ }^{1}$ School of Management, Universiti Sains Malaysia \\ ${ }^{2}$ Graduate School of Business, Universiti Sains Malaysia \\ ${ }^{3}$ Jazan University, KSA \\ Correspondence: Khairul Anuar Mohammad Shah, School of Management, Universiti Sains Malaysia, 11800 USM, \\ Penang, Malaysia.
}

Received: July 5, 2020

Accepted: September 4, 2020

Online Published: September 21, 2020

doi:10.5430/ijhe.v9n6p190

URL: https://doi.org/10.5430/ijhe.v9n6p190

\begin{abstract}
This study focuses on the effect of globalization on university ranking and current developments and challenges that HEIs face in the global higher education market. It provides detailed information about the origins of international ranking systems, diversification of university rankings and strategic planning of higher education institutes. Moreover, this study describes the global university classification, continuous exposure to elite universities, neglect of the humanities, arts and the social sciences researches, limited description of methods and indigent metrics. The expected effects on ranking system amid the COVID-19 crisis are mentioned which are widely being discussed by the researchers. The study concludes that there is a threat that universities which are investing time and money in accumulating and using statistics and data for the sake of improvement in their performance for the rankings may destabilize themselves from the development in other areas such as learning, teaching or community involvement.
\end{abstract}

Keywords: university rankings, internationalization, COVID-19, globalization

\section{Introduction}

Globalization and internationalization forces propel higher education institutes (HEI) to prepare for the battle of global university rankings. This article focuses on the impact of globalization on university ranking and contemporary trends and challenges facing by HEIs to strive in the global higher education industry. The global/international ranking is a hotly debated issue that is shifting in its role and scope (Kehm \& Stensaker, 2009; King, 2015). It is appreciable that international rankings are diversifying and moving towards more broadly balanced criteria and becoming multidimensional (Yudkevich, Altbach, \& Rumbley, 2016), however, competition and international comparisons are not without challenges and consequences.

Whilst developed countries such as United States, Australia, Canada and Germany generally view global rankings as a challenge to their leading position in the higher education sector (Marginson \& Van der Wende, 2007; Marginson, 2007; Hazelkorn, 2015). Whereas, developing or middle-income countries like Malaysia, Pakistan, India Saudi Arabia usually treat global rankings more compassionately (Thakur, 2007; Shin \& Harman, 2009; Marginson, 2009). Rankings can be considered as a beneficial accountability tool, particularly for institutions where such practices are immature or weak. Therefore, they can lead higher education institutions to "the global knowledge network on an equal basis with the top academic institutions in the world" (Altbach et al., 2011, pg 319)

\section{The Origins of International Rankings}

The notion of comparison among universities is historical, where ranking universities was practised around 1900 in England with the publication of "Where We Get Our Best Men" (Maclean, 1900). The study focused on the backgrounds of the highly successful and most prominent men with a focus on the institutions where they studied. Consequently, the list of universities classified by the numbers of eminent alumni was produced and published (Myers $\&$ Robe, 2009). Though the practice was rapidly rivalled in other countries, it gained a little debate outside academic institutions. Later, the next eighty years carried some other studies on rankings, particularly in graduate programs but still unnoticed by society in general. The wide-ranging interest in university rankings began in 1983 with one publication by US News and World Report titled 'America's Best Colleges' (Lukman, Krajnc \& Glavič, 2010). The information related to undergraduate programs in US higher education institutions was publicly and widely available for the first time in history. These statistics were accessible widespread among the parents and the general population 
of high schools. A couple of years later, the first "Good University Guide" was issued by The Times in the United Kingdom in 1993 (O'leary, 2010), stimulating the public debate concerning the institution's choice of good and bad. Subsequently, the 1990 decade witnessed the fame of global rankings. However, the well-swept over this sector was initiated by the the Academic Ranking of World Universities (ARWU) in China started by Shanghai Jiao Tong University (Liu \& Cheng, 2005). Later in 2004, the Times Higher Education-QS World University Rankings was introduced by Times Higher Education (THE), a British magazine. Times Higher Education (THE) with the association of Quacquarelli Symonds (QS) issued the annual Times Higher Education-QS World University Rankings. Meanwhile, QS rated 500 top universities whereas, THE focused on the top 200 and released the data via media partners (Aguillo, Bar-Ilan, Levene, \& Ortega, 2010). In 2009, THE parted from QS and started the collaboration with Thomson Reuters and announced a new ranking titled 'Times Higher Education World University Rankings' (Huang, 2012). Afterwards, the ranking system was one of the highlighted topic to be researched by the researchers (Hazelkorn, 2015 ) and now the topic has increasingly engrossed more anti-ranking discussions and initiatives (Marope \& Wells, 2013; Mmantsetsa, Peter \& Silvia, 2014).

\section{Diversification of University Rankings}

The last decade has witnessed diversity and innovation in global university rankings. Particularly, from the past few years, several new rankings have been introduced in the education industry with distinction in methodology and evaluation factors such as academic performance, innovativeness, and internationalization presence (Shin, Toutkoushian \& Teichler, 2011; Aguillo, Ortega \& Fernández, 2008). However, research including several citations for published articles is considered as an essential indicator in the evaluation process by most of the ranking establishments (Shin, Toutkoushian, \& Teichler, 2011).

The major newsworthy global rankings include: the Academic Ranking of World Universities (ARWU, also known as Shanghai rankings); the Times Higher Education World University Rankings (THE), and the QS (Quacquarelli Symonds Limited) World University Rankings (Chen \& Liao, 2012). Other rankings for instance "The Center for World University Rankings (CWUR), G-factor and Reuters World's Top 100 Innovative Universities failed to attract higher media attention, but are still substantial within the academic world. Table 1 lists numerous existing global university rankings-inclusive of their origins, established years, and methodologies.

Table 1. Types of rankings

\begin{tabular}{l}
\hline Ranking \\
\hline Academic Ranking of World \\
Universities \\
Times Higher Education World \\
University Rankings
\end{tabular}

\section{Times Higher Education World Reputation Rankings}

Young University Rankings

QS World University Rankings

QS Asian University Rankings QS Latin American University
Rankings

Center for World University Rankings

\begin{tabular}{|c|c|}
\hline Origin & Methodology / Indicators \\
\hline Shanghai & -No: of published articles (N \\
\hline \multirow[t]{8}{*}{ Consultancy, China } & -Fields Medalists (mathemat \\
\hline & -No: of Nobel Prize winners \\
\hline & Five groups of performance \\
\hline & -Research (volume, income \\
\hline & -Teaching (the learning envir \\
\hline & -Citations (research influenc \\
\hline & -Industry income (knowledge \\
\hline & - International outlook (staff, \\
\hline \multirow{4}{*}{$\begin{array}{l}\text { Times Higher Education } \\
\text { (THE), UK }\end{array}$} & research and students) \\
\hline & Five indicators: \\
\hline & - Academic peer review \\
\hline & - International staff ratio \\
\hline \multirow[t]{4}{*}{ Quacquarelli Symonds, UK } & -International student ratio \\
\hline & - Citations per faculty \\
\hline & - Employer reputation \\
\hline & - Faculty/Student ratio \\
\hline the Center for World & - Quality of education \\
\hline University Rankings, Suadi & -Scientific impact \\
\hline
\end{tabular}




Eduniversal Business School
Ranking
Leiden Ranking
Professional Ranking of World
Universities

Reuters World's Top 100 Innovative Universities

SCImago Institutions Rankings

U-Multirank

UniRanks "The Ranking of
Rankings" Thoms

Androulla Vassiliou, Commissioner for Higher Education and Culture, Belgium

SCImago Research Group,

UniRanks World University Ranking
- Number of publications

- Number of publications in high-quality journals

- Citations

- Alumni employment

- Number of patents

- Quality of faculty

- Official Selection of the best 1000 Business Schools

- Palmes of Excellence classification (from 1 to 5)

- Dean's vote

Bibliometric normalization and impact indicators:

- Citations-per-publication

- Including the number of publications

- Field-averaged impact per publication

The number of Chief Executive Officers (or equivalent) among the Fortune Global 500

- Patent Volume

- Total Web of Science Papers

- Patent Success

- Global Patents

- Patent Citations

- The patent to Article Citation Impact

- Per cent of Industry Collaborative Articles

- Patent Citation Impact

- Per cent of Patents Cited

- Industry Article Citation Impact

Based on 13 separate indicators grouped into five categories:

- Teaching

- International mix

- Citations

- Research

- Industry income

Based on 30 separate indicators and rated in five performance groups, from 'A' (very good) through 'E' (weak)

Use the following rankings and weights:

- THE

Innovative Universities

- QS

- US News Best Global University 


\begin{tabular}{|c|c|c|}
\hline & & $\begin{array}{l}\text { - ARWU } \\
\text { - Reuters World Top } 100\end{array}$ \\
\hline $\begin{array}{l}\text { U.S. News \& World Report's Best } \\
\text { Global Universities Rankings }\end{array}$ & $\begin{array}{l}\text { U.S. News \& World Report, } \\
\text { USA }\end{array}$ & $\begin{array}{l}\text { Judging by factors such as: } \\
\text { - Publications } \\
\text { - Global research reputation } \\
\text { - Number of highly cited papers }\end{array}$ \\
\hline Webometrics & Cybermetrics Lab, Spain & $\begin{array}{l}\text { Based on a composite indicator that considers } \\
\text { both the volume of the Web contents (number } \\
\text { of web pages and files) and the visibility and } \\
\text { impact of these web publications according to } \\
\text { the number of external links (site citations) } \\
\text { they received }\end{array}$ \\
\hline
\end{tabular}

Source: topuniversities.com, THE, Rathenau Institute, UniversityRankings.ch

\section{Globalization and World University Rankings}

The academic world in the 21 st century is considered more market-oriented and competitive where international rankings are unavoidable and essential (Hazelkorn, 2015). Globalization affects regions, countries, and cultures in diverse ways, and higher education was also affected by globalization (Knight, 2008). Thus, in the last few years, there have been huge changes in the higher education sector, and demand for global competitiveness and completeness is quite prominent and evident (Rust \& Kim, 2012). In accordance with globalization and the development of the global knowledge economy, these competitive forces lead to global comparisons and assessments.

The growing relevance of the global universities rankings get recognition all over the world and these rankings allow evaluation of the quality of the higher education and its competitiveness in the educational market. Today, rankings have placed themselves as gatekeepers for higher education, defining what and who is appraised, and to what extent.

\section{Global Rankings and University's Strategic Planning}

\subsection{National Efforts to Develop World-Class Universities}

Altbach (2003) explains that the desire to have world-class universities can be seen in every country. However, the limited cognizance about what a world-class university is and how to get it is quite challenging. At one time, the government's role in the development of world-class universities was not considered a critical factor. For instance, the Ivy League universities in the US disclose that, they nurtured to superiority because of incremental progress, instead of deliberate intervention by the government (Salmi, 2009). Likewise, the Universities of Oxford and Cambridge grew over the centuries due to their own volition (Smith \& Ho, 2006).

Essential elements while adopting the goal of establishing world-class universities are; an integrated teaching system, innovative research environment and digitalized, technology-oriented institutions (Salmi, 2009). However, in current times it is unlikely that a world-class university can be quickly created without an adequate national policy and direct support from the government. In that respect, standardization, quality assurance, and funding for research projects are some of the key policies playing a role in developing a world-class university.

\subsection{Quality Assurance Practices}

In the current era of rapid globalization, quality assurance has been regarded as a primary concern in the global rankings of the universities (Myers \& Robe, 2009). The rapid expansion of students, propagation of institutions, student overseas mobility, and some other factors have pushed policymakers to attend to quality and accountability. Historically, the key focus of most nations has been to raise enrolments and access, however, now the focus is moving towards quality and the global ranking playing a leading role in this shift (Blanco-Ramírez \& B. Berger, 2014).

What quality assurance practices should a university follow to become world-class? A world-class university should attain the following three major competence roles: (1) students' educational quality, (2) research, dissemination and development of knowledge, and (3) initiatives making a contribution to the community and the society (Levin, Jeong, $\& \mathrm{Ou}, 2006)$. Despite these factors, most of the well-known rankings seek out quality of research rather than teaching quality.

Quality assurance is based on the three fundamental criteria which are: control, improvement and accountability (Parry, 2006). In the case of universities, quality assurance can be dispersed into external and internal quality 
assurances. Internal quality assurance focuses on the development of institution and internal accountability assessment, whereas, external quality assurance focuses on attaining public accountability (Newton, 2000). Both are essential for a university to prove to keep its standing in global international rankings. Quality assurance practices such as external review and Internal self-evaluation, directed openly by independent experts, are vibrant for enhancing the institutional quality.

\subsection{Internationalization of Universities}

The rationalisations classified in the literature to internationalize a university are academic, economic social and political (Knight, 2004; Kreber, 2009; Qiang, 2003). Academic motives for internationalization are based on meeting the need for the educational mission and approaches of the university, remaining academically relevant in an interconnected globalized society, and attracting the best students and faculty around the world. Internationalization, from the last two decades, is an important aspect where universities are focusing to be more global and competent (Myers \& Robe, 2009). The conventional features which determine the internationalization level at any institution are; inbound mobility of foreign students, students exchange programs, international faculty, and international contents in educational courses (Khalid, Ali, Islam, Khaleel, \& Shu, 2017).

Global rankings consider internationalization as an important indicator for the evaluation process, for example, THE World University Rankings has an international outlook as a performance indicator with a given weight 7.5\%. The QS World University Rankings, give $10 \%$ weight to internationalization indicators which are equally divided into the proportion of international faculty and international students (Shin et al., 2011; Topuniversities, 2017). Thus, universities that desire to stay world-class in the rankings have to focus on their internationalization policies, exclusively on increasing the enrollment of international students, academic/staff mobility, co-authored international research publications, and English as an instructional medium.

\section{Consequences and Prospects of Global University Rankings}

The yearly composite rankings of universities do not always satisfactorily accomplish the university's demands. The reality is that no ranking is without limitations and consequences. Key deficits and limitations refer to the continued focus on elite universities (Weingart \& Maasen, 2007), the relative neglect of the arts, social sciences and humanities (Kanhere, Arjunwadkar \& Vichare, 2009), superficial methodology description and poor indicators (Taylor \& Braddock, 2007), self-critical attitude to rankings from the providers (Amsler \& Bolsmann, 2012), inadequacies in identifying and directing institutional diversity (Dill \& Soo, 2005), and anticipated commercial interests (Kiraka, Maringe, Kanyutu \& Mogaji, 2020).

\subsection{Continued Attention towards Elite Universities}

The analysis of the procedures following by different ranking systems in a selection of universities exposed that the applied methodologies were not covering most universities, and consequently could not deliver a comprehensive basis for analyzing complete higher education systems. ARWU ranking principally chooses universities based on highly cited researchers, the number of Nobel Prize winners, and the published articles in Science or Nature (Salmi, 2016). The Leiden Ranking (CWTS) chooses universities which have at least 500 papers publications in Web of Science (WoS) for five consecutive years, but discounts the publications in the fields of humanities and arts. QS also selects its top higher education institutions worldwide based on per paper citations before applying further indicators such as reputation survey performance, domestic ranking performance, and geographical balancing (Aguillo et al., 2010). However, there is no further explanation of how those criteria are applied.

In THE World University Ranking system, the procedure regarding the selection of universities is not available on THE methodology page (Rauhvargers, 2013). Organizing academic reputation surveys also indicates the selection of elite universities, and additionally, the high-rank positions attained by a small group of higher education institutes are often self-perpetuating.

\subsection{Relative Negligence of the Humanities, Arts and the Social Sciences}

The humanities, arts and especially the social sciences fields remain underrepresented in the international rankings (Kanhere, Arjunwadkar \& Vichare, 2009). This inattention comes from insistent biases that persist in field-normalized citation counts and bibliometric indicators, despite substantial improvements in methodology (Benneworth \& Jongbloed, 2010). This characterizes that citation impacts are more reliably determined through indicators measuring the proportion of publications in highly cited journals (Van Raan, 2005), and therefore favours those research areas in which these articles are focused, namely natural sciences, medicine and engineering (Perkmann et al., 2013). Moreover, these are the most significant fields in the Elsevier and Thomson Reuters databases and thus determine, to a 
substantial extent, performance in the rankings worldwide. In the humanities, arts, and social sciences research, the output of the published article is typically concerted in books.

\subsection{Shallow Descriptions of Methodology and Indigent Indicators}

In the process to normalize bibliometric indicators, there is often no reference to the normalization method being adopted (Van, 2005). Although regional weights are sometimes declared, their standards and values remain unrevealed. For instance, in the methodology of the QS description, it is stated that the world's top universities are chosen on the base of citations per paper, nevertheless, several other indicators are also put into consideration, such as reputation survey performance, domestic ranking performance, direct case submission, and geographical balancing (Taylor \& Braddock, 2007). The further explanation about how they are applied is absent (QS, 2016). Besides this, the use of poor and indigent indicators also persists in global ranking systems. Despite prevalent criticism, reliance on reputation factors is becoming more widespread. Furthermore, regardless of the controversy regarding indicators of staff/student ratio, they are still commonly used to measure the teaching performance.

\subsection{Provider's More Self-Critical Attitude to Rankings}

Some of the ranking providers such as Webometrics recently moved from distancing themselves from the potentially adversative effects of rankings to giving warnings about how the produced results may be misused (Federkeil, 2002). The introduction of new implications that would discourse these inadequacies would be more obliging (Saisana, d'Hombres, \& Saltelli, 2011). For instance, THE ranking output could be demonstrated by individual indicators, rather than an aggregated 'ranking criteria' that is the combination of five diverse indicators.

Among the ranking's limitations identified by Elsevier, the use of superficial and one-dimensional measurement indicators for sophisticated institutions, allows for variances in institutional size, and dependence on proxies to evaluate teaching performance as appropriate criteria are seemingly unavailable. Elsevier also advises that excessive reliance on East Asia rankings, particularly in research funds allocation, may be disadvantageous for the higher education systems towards development and progress. In summary, this trend is growing amongst ranking providers to converse openly the probable pitfalls. It is imperative to make certain that decision-makers are mindful of the limitations of the rankings results. The growing inclination of providers to raise voices is an inspiring first sign that progress may be ensured in the near future.

\subsection{Commercial Interests/Commercializing Core Business}

Rankings are a fruitful and rewarding business model, however, as a result of the commercial interest in preserving the position and growing competition among universities (Kehm, 2014), their impact is unlikely to decay anytime soon. How rankings now act as a consultant is through shaping what Holmes (2013), author of "Watching the Rankings", defines it the prestigious events in spectacular settings. He exemplifies these events as a lucrative mix of business opportunities including customized rankings, conferences, consultancy, and workshops for world-class wannabes" (Holmes, 2013, pg 41). Moreover, according to Holmes, "a huge commercial success based on the participation rates charged, and their frequency" (Holmes, 2013. pg 27). University rankings industry is now full of discernment of conflict of interest and self-centeredness, in consort with self-appointed auditors (Hazelkorn, 2013a), which may not productive for the higher education industry in a true sense.

\section{The Expected Change in Trend during COVID-19}

From the perspective of university ranking systems, the data collection for the year 2021 was managed because the corresponding data period occurred for most of the metrics before the COVID-19 crisis took hold, and most of the agencies had already launched their ranking for the year 2021, e.g. the Time Higher Education, QS-World ranking. They include publications from 2015 to 2019 and citations from 2015 to-date for bibliometric information. According to THE (2020), data that overlap with the present situation will be used for the next year's University Rankings. The scores of universities can be influenced only by papers cited extremely quickly (THE, 2020). Regarding the internationalisation, the numbers of international students will decrease, but how far and for how long is unsure. One of the major losses in the academic research universities is apparent from now that the shortcomings of Erasmus in Europe, which has been a highly productive program for internationalisation, can be traced.

Despit the shortcomings of scholarships and governmental fundings, the students will still want to make the best choice for their education and can opt for admissions abroad via an online platform. To address COVID issue, researchers have been working on how universities are coping with this challenging period (Viner, et al., 2020; Ilmiyah \& Setiawan, 2020; Zhong, et al., 2020). According to the report by Times Higher Education (2020), research will hit universities in Australia and the United Kingdom, and the impact will vary between countries and ranking institutions. Addressing the pandemic's impact on universities and their ranking, which is highly dependent on the students' 
enrolment, Sahu (2020) suggests that universities need to strategically plan ways forward to manage admissions for new academic sessions. The admission departments must consider online applications from potential students and provide them with more convenient admission procedures to maintain their number of international students. Moreover, changes in academic research outcomes are also expected, yet it is again difficult to ascertain what effect this will have (Setiawan, 2020), but it is predicted that the parameters to rank the universities will be revised (THE, 2020).

\section{Conclusion and Future Stance}

The new forms of competition standards, research, international educational activities, and engagements are showing new and specialized forms of global rankings. The influx of global rankings over the past few years has engrossed considerable attention on the advancement of higher education, and placed a spotlight on the local and international comparison of universities. University rankings have undeniably facilitated to foster better responsibility, accountability, and amplified pressure to expand management practices in the tertiary sector.

Over the past couple of months, however, several analysts have argued that the impact of COVID-19 would be significant and permanent upon economics, education and rankings for higher education (Viner, et al., 2020; Ilmiyah \& Setiawan, 2020; Zhong, et al., 2020), and early budget and policy and academic opinions are somewhat pessimistic.

While no short-term remedies are apparent, there are helpful approaches to boost the long-term internationalization of university rankings. Some of the basic higher education financial and implementation problems pre-date the COVID-19 pandemic, are exacerbated and will continue despite it. Efforts to improve trends in the long term should commence immediately. Currently, it would be difficult to argue that the offered benefits through information and results providing by these rankings, given the observed deficiency in transparency, are greater than the unwelcomed consequences. Nevertheless, there is a threat that universities that are investing time and money in accumulating and using statistics and data for the sake of improvement in their performance for the rankings, may destabilize themselves from the development in other areas such as learning, teaching or community involvement.

\section{References}

Aguillo, I. F., Bar-Ilan, J., Levene, M., \& Ortega, J. L. (2010). Comparing university rankings. Scientometrics, 85(1), 243-256. https://doi.org/10.1007/s11192-010-0190-Z

Aguillo, I. F., Ortega, J. L., \& Fernández, M. (2008). Webometric ranking of world universities: Introduction, methodology, and future developments. Higher Education in Europe, 33(2-3), 233-244. https://doi.org/10.1080/03797720802254031

Altbach, P. (2015). The dilemmas of ranking. International Higher Education, (42). https://doi.org/10.6017/ihe.2006.42.7878

Altbach, P. G. (2003). Globalization and the university: Myths and realities in an unequal world. Current Issues in Catholic Higher Education, 23(1), 5-26.

Altbach, P. G., Salmi, J., Wang, Q. H., Wang, Q., Liu, N. C., Postiglione, G. A., \& Jayaram, N. (2011). The road to academic excellence: The making of world-class research universities. World Bank. https://doi.org/10.1596/978-0-8213-8805-1

Amsler, S. S., \& Bolsmann, C. (2012). University ranking as social exclusion. British Journal of Sociology of Education, 33(2), 283-301. https://doi.org/10.1080/01425692.2011.649835

Anafinova, S. (2020). Rankings in the political economy, neo-liberal and new institutional research (PRE-PRINT DRAFT). Saule Anafinova. ELTE Doctoral School of Education. https://doi.org/10.31235/osf.io/pjbv3

Bekhradnia, B. (2016). International university rankings: For good or ill? Oxford, UK: Higher Education Policy Institute.

Benneworth, P., \& Jongbloed, B. W. (2010). Who matters to universities? A stakeholder perspective on humanities, arts and social sciences valorisation. Higher Education, 59(5), 567-588. https://doi.org/10.1007/s10734-009-9265-2

Blanco-Ramírez, G., \& B. Berger, J. (2014). Rankings, accreditation, and the international quest for quality: Organizing an approach to value in higher education. Quality Assurance in Education, 22(1), 88-104. https://doi.org/10.1108/QAE-07-2013-0031

Chen, K.-h., \& Liao, P.-y. (2012). A comparative study on world university rankings: a bibliometric survey. Scientometrics, 92(1), 89-103. https://doi.org/10.1007/s11192-012-0724-7 
Dearden, J. A., Grewal, R., \& Lilien, G. L. (2019). Strategic manipulation of university rankings, the prestige effect, and student university choice. Journal of Marketing Research, 56(4), 691-707. https://doi.org/10.1177/0022243719831258

Dill, D. D., \& Soo, M. (2005). Academic quality, league tables, and public policy: A cross-national analysis of university ranking systems. Higher Education, 49(4), 495-533. https://doi.org/10.1007/s10734-004-1746-8

Erkkilä, T., \& Piironen, O. (2020). Trapped in university rankings: bridging global competitiveness and local innovation. International Studies in Sociology of Education, 29(1-2), 38-60. https://doi.org/10.1080/09620214.2019.1634483

Estera, A., \& Shahjahan, R. A. (2019). Globalizing whiteness? Visually re/presenting students in global university rankings websites. Discourse: Studies in the Cultural Politics of Education, 40(6), 930-945. https://doi.org/10.1080/01596306.2018. 1453781

Federkeil, G. (2002). Some Aspects of Ranking Methodology--The CHE-Ranking of German Universities. Higher Education in Europe, 27(4), 389-397. https://doi.org/10.1080/0379772022000071878

Hazelkorn, E. (2013a). How Rankings are Reshaping Higher Education. in Climent, V., Michavila, F. and Ripolles, M. (eds.). Los Rankings Univeritarios. Mitos y Realidades.

Hazelkorn, E. (2013b). World-Class Universities or World Class Systems? Rankings and Higher Education Policy Choices. Palgrave Macmillan. UK.

Hazelkorn, E. (2015). Rankings and the reshaping of higher education: The battle for world-class excellence. https://doi.org/10.1057/9781137446671

Holmes, R. (2013). Watching the rankings. Selected Writings on International University Rankings and Related Topics. CreateSpace Independent Publishing Platform.

Huang, M.-H. (2012). Opening the black box of QS World University Rankings. Research Evaluation, 21(1), 71-78. https://doi.org/10.1093/reseval/rvr003

Ilmiyah, S., \& Setiawan, A. R. (2020). Students' Worksheet for Distance Learning Based on Scientific Literacy in the Topic Coronavirus Disease 2019 (COVID-19). https://doi.org/10.35542/osf.io/wyz5v

Instituut, R. (2017). The Rathenau Instituut, Rankings. Retrieved from https://www.rathenau.nl/en/page/rankings

Kanhere, D., Arjunwadkar, M., \& Vichare, A. (2009). Rise and decline of India's state university system: Neglect, design or neglect by design? Current Science, 97(7), 1013-1021. Retrieved from http://www.jstor.org/stable/24112044

Kehm, B. M. (2014). Global university rankings-Impacts and unintended side effects. European Journal of Education, 49(1), 102-112. https://doi.org/10.1111/ejed.12064

Kehm, B. M., \& Stensaker, B. (2009). University rankings, diversity, and the new landscape of higher education (Vol. 18). Sense Publishers.

Khalid, J., Ali, A. J., Islam, M. S., Khaleel, M., \& Shu, Q. F. (2017). Internationalization as Investment for Higher Education Institutions: Introducing a Framework to Enhance Investment in Internalization Practices. Review of Social Sciences, 2(2), 1-11. https://doi.org/10.18533/rss.v2i2.87

King, R. (2015). Institutional Autonomy and Accountability. In: Huisman J., de Boer H., Dill D.D., Souto-Otero M. (eds.) The Palgrave International Handbook of Higher Education Policy and Governance. Palgrave Macmillan, London. https://doi.org/10.1007/978-1-137-45617-5_26

Kiraka, R., Maringe, F., Kanyutu, W., \& Mogaji, E. (2020) University league tables and ranking systems in Africa: emerging prospects, challenges and opportunities. In: Mogaji, Emmanuel, Maringe, Felix and Hinson, Robert, (eds.) Understanding the Higher Education Market in Africa. Routledge Studies in Marketing. Routledge, Oxfordshire, UK. https://doi.org/10.4324/9780429325816-15

Knight, J. (2004). Internationalization remodelled: Definition, approaches, and rationales. Journal of Studies in International Education, 8(1), 5-31. https://doi.org/10.1177/1028315303260832

Knight, J. (2008). The internationalization of higher education: Complexities and realities. Higher education in Africa: The international dimension, 1-43. https://doi.org/10.1163/9789087905224_002 
Kreber, C. (2009). Different perspectives on internationalization in higher education. New directions for teaching and learning, 118, 1-14. https://doi.org/10.1002/tl.348

Levin, H. M., Jeong, D. W., \& Ou, D. (2006). What is a world class university. Paper presented at the Conference of the Comparative and International Education Society, Honolulu, HI, March.

Liu, N. C., \& Cheng, Y. (2005). The academic ranking of world universities. Higher Education in Europe, 30(2), 127-136. https://doi.org/10.1080/03797720500260116

Lukman, R., Krajnc, D., \& Glavič, P. (2010). University ranking using research, educational and environmental indicators. Journal of Cleaner Production, 18(7), 619-628. https://doi.org/10.1016/j.jclepro.2009.09.015

Luque-Martínez, T., \& Faraoni, N. (2020). Meta-ranking to position world universities. Studies in Higher Education, 45(4), 819-833. https://doi.org/10.1080/03075079.2018.1564260

Maclean, A. H. H. (1900). Where we get our best Men. Some statistics showing their nationalities, counties, towns, schools, universities, and other antecedents. 1837-1897, London.

Marginson, S. (2007). Global university rankings: Implications in general and for Australia. Journal of Higher Education Policy and Management, 29(2), 131-142. https://doi.org/10.1080/13600800701351660

Marginson, S. (2009). University rankings, government and social order: Managing the field of higher education according to the logic of the performative present-as-future. In Re-reading education policies, 584-604. https://doi.org/10.1163/9789087908317_030

Marginson, S., \& Van der Wende, M. (2007). To rank or to be ranked: The impact of global rankings in higher education. Journal of Studies in International Education, 11(3-4), 306-329. https://doi.org/10.1177/1028315307303544

Marope, M., \& Wells, P. (2013). University Rankings: The Many Sides of the Debate. Rankings and Accountability in Higher Education: Uses and Misuses, 7.

Mmantsetsa, M., Peter J, W., \& Silvia, F. (2014). University Rankings: The Many Sides of the Debate. Management of Sustainable Development, 6(1). https://doi.org/10.2478/msd-2014-0006

Myers, L., \& Robe, J. (2009). College Rankings History, Criticism and Reform. ERIC - Education Resources Information Center, Center for College Affordability and Productivity, files.eric.ed.gov/fulltext/ED536277.pdf

Newton, J. (2000). Feeding the Beast or Improving Quality?: academics' perceptions of quality assurance and quality monitoring. Quality in Higher Education, 6(2), 153-163. https://doi.org/10.1080/713692740

O'leary, J. (2010). The times good university guide 2011. HarperCollins UK.

Parry, G. (2006). Policy-participation trajectories in English higher education. Higher Education Quarterly, 60(4), 392-412. https://doi.org/10.1111/j.1468-2273.2006.00330.x

Perkmann, M., Tartari, V., McKelvey, M., Autio, E., Broström, A., D’Este, P., ... Sobrero, M. (2013). Academic engagement and commercialisation: A review of the literature on university-industry relations. Research Policy, 42(2), 423-442. https://doi.org/10.1016/j.respol.2012.09.007

Peters, M. A. (2019). Global university rankings: Metrics, performance, governance. Educational Philosophy and Theory, 51(1), 1-9. https://doi.org/10.1080/00131857.2017.1381472

Qiang, Z. (2003). Internationalization of higher education: Towards a conceptual framework. Policy Futures in Education, 1(2), 248-270. https://doi.org/10.2304/pfie.2003.1.2.5

QS. (2016). QS World university ranking methodology. Retrieved from https://www.topuniversities.com/qs-world-university-rankings/methodology

Rauhvargers, A. (2013). Global university rankings and their impact: Report II: European University Association Brussels.

Rust, V. D., \& Kim, S. (2012). The global competition in higher education. World Studies in Education, 13(1), 5-20. https://doi.org/10.7459/wse/13.1.02

Sahu, P. (2020). Closure of universities due to Coronavirus Disease 2019 (COVID-19): impact on education and mental health of students and academic staff. Cureus, 12(4). https://doi.org/10.7759/cureus.7541

Saisana, M., d'Hombres, B., \& Saltelli, A. (2011). Rickety numbers: Volatility of university rankings and policy implications. Research Policy, 40(1), 165-177. https://doi.org/10.1016/j.respol.2010.09.003 
Salmi, J. (2009). The challenge of establishing world-class universities. World Bank Publications. https://doi.org/10.1596/978-0-8213-7865-6

Salmi J. (2016). Excellence Strategies and the Creation of World-Class Universities. In: Liu N.C., Cheng Y., Wang Q. (eds.) Matching Visibility and Performance. Global Perspectives on Higher Education. SensePublishers, Rotterdam. https://doi.org/10.1007/978-94-6300-773-3_2

Setiawan, A. R. (2020). Scientific Literacy Worksheets for Distance Learning in the Topic of Coronavirus 2019 (COVID-19). https://doi.org/10.35542/osf.io/swjmk

Shin, J. C., \& Harman, G. (2009). New challenges for higher education: Global and Asia-Pacific perspectives. Asia Pacific Education Review, 10, 1-13. https://doi.org/10.1007/s12564-009-9011-6

Shin, J. C., Toutkoushian, R. K., \& Teichler, U. (2011). University rankings: Theoretical basis, methodology and impacts on global higher education (Vol. 3): Springer Science \& Business Media. https://doi.org/10.1007/978-94-007-1116-7

Smith, H. L., \& Ho, K. (2006). Measuring the performance of Oxford University, Oxford Brookes University and the government laboratories' spin-off companies. Research Policy, 35(10), 1554-1568. https://doi.org/10.1016/j.respol.2006.09.022

Taylor, P., \& Braddock, R. (2007). International university ranking systems and the idea of university excellence. Journal of Higher Education Policy and Management, 29(3), 245-260. https://doi.org/10.1080/13600800701457855

Thakur, M. (2007). The impact of ranking systems on higher education and its stakeholders. Journal of Institutional Research, 13(1), 83-96.

Topuniversities. (2017). World University Ranking Methodologies Compared. Retrieved from https://www.topuniversities.com/university-rankings-articles/world-university-rankings/world-university-rankin g-methodologies-compared

THE. (2016). Times Higher $\quad$ Education. Retrieved from https://www.timeshighereducation.com/news/ranking-methodology-2016

THE. (2020). Times Higher Education. Retrieved from https://www.timeshighereducation.com/world-university-rankings/what-might-covid-19-mean-world-universit y-rankings\#

Van Raan, A. F. (2005). Fatal attraction: Conceptual and methodological problems in the ranking of universities by bibliometric methods. Scientometrics, 62(1), 133-143. https://doi.org/10.1007/s11192-005-0008-6

Viner, R. M., Russell, S. J., Croker, H., Packer, J., Ward, J., Stansfield, C., ... Booy, R. (2020). School closure and management practices during coronavirus outbreaks including COVID-19: a rapid systematic review. The Lancet Child \& Adolescent Health. https://doi.org/10.2139/ssrn.3556648

Weingart, P., \& Maasen, S. (2007). Elite through rankings-The emergence of the enterprising university. In The changing governance of the sciences (pp. 75-99). Springer, Dordrecht. https://doi.org/10.1007/978-1-4020-6746-4_4

Yudkevich, M., Altbach, P. G., \& Rumbley, L. E. (2016). The Global Academic Rankings Game: Changing Institutional Policy, Practice, and Academic Life. Routledge. https://doi.org/10.4324/9781315677170

Zhong, B. L., Luo, W., Li, H. M., Zhang, Q. Q., Liu, X. G., Li, W. T., \& Li, Y. (2020). Knowledge, attitudes, and practices towards COVID-19 among Chinese residents during the rapid rise period of the COVID-19 outbreak: A quick online cross-sectional survey. International Journal of Biological Sciences, 16(10), 1745-1752. https://doi.org/10.7150/ijbs.45221

\section{Copyrights}

Copyright for this article is retained by the author(s), with first publication rights granted to the journal.

This is an open-access article distributed under the terms and conditions of the Creative Commons Attribution license (http://creativecommons.org/licenses/by/4.0/). 